\title{
А.I. Решетченко
}

Харківський національний університет міського господарства імені О. М. Бекетова, Украӥна

\section{РЕКОМЕНДАЦІЇ ЩОДО ВПРОВАДЖЕННЯ МОНІТОРИНГУ ШУМУ ВУЛИЧНО-ДОРОЖНЬОЇ МЕРЕЖІ НАСЕЛЕНИХ МІСТ}

Головним джерелом шумового забруднення міст України є автотранспорт. В роботі обтрунтовано необхідність проведення моніторингу шуму вулично-дорожньої мережі та надано рекомендаџії щодо організаиії порядку моніторингу шуму. Отримані результати моніторингу шуму надають змогу виявити дискомфортні зони селітебних територій для населення та можуть використовуватися для оптимізації та зниження впливу шуму на екосистему міста.

Ключові слова: шум, моніторинг, автотранспорт, спостереження, автомобільна дорога.

\section{Постановка проблеми}

Однією із нагальних проблем екологічної безпеки в Україні є стан акустичного забруднення. У великих містах основним джерелом шумового навантаження $€$ автотранспорт, що слугує причиною виникнення ризику для здоров'я населення внаслідок локального підвищення акустичного рівня шуму. Доведено, що міський шум негативно впливає на організм людини, вражає слухові органи, центральну нервову систему, може викликати хвороби серця і судин. Перевищенні рівні шуму заважають відпочинку, що впливає на робочу продуктивність. Оскільки негативний вплив на здоров'я населення наднормативних рівнів шуму автотранспорту вже достатньо вивчений, то у країнах Свросоюзу приділяють велику увагу управлінню акустичним забрудненням на урбанізованих територіях. В Україні ця проблема потребує більш детального вивчення, адже наразі відсутній порядок проведення моніторингу шуму та комплексні моніторингові дослідження акустичних рівнів шуму автомобільнодорожньої мережі населених міст, що і зумовлює актуальність даної статті.

\section{Аналіз останніх досліджень і публікацій}

Стрімка урбанізація міст за останнє десятиріччя призвела до значного збільшення міських мешканців, що стало причиною зростання кількості наземного транспорту. Існуючі вулично-дорожні мережі у багатьох містах України не розраховані на сучасну кількість транспорту, а дорожнє покриття потребує капітального ремонту. Усі ці фактори стають причиною перевищення допустимих рівнів шуму та погіршують екологічно безпечний стан акустичного простору. Надзвичайно гостро стоїть проблема розташування вулично-дорожньої мережі поблизу житлових масивів міст. Шум, що виникає внаслідок роботи транспортних засобів, негативно впливає на здоров'я населення.

Негативна тенденція до збільшення транспортного шуму набула чіткого підтвердження у наукових публікаціях українських та зарубіжних дослідників. Багатьма науковцями [1-7] проводилися натурні вимірювання рівнів автотранспортного шуму в різних містах України. Кожен із наведених авторів у своїх доробках фіксує наднормативні перевищення рівнів транспортного шуму.

Варто зазначити, що у приведених публікаціях, авторами проводились експерименти із визначення звукових характеристик транспортного потоку, що не обмежені у часі. Тобто кожний окремий автор обирає зручний час для проведення експерименту, спираючись, загалом, на «години пік» транспортного руху, в яких можливо зафіксувати найвищі покажчики рівнів шуму, виникаючих за рахунок роботи транспортних засобів. Ділянки, обрані для проведення експериментів також не мають конкретних прив'язок. Зазвичай, досліджується центральна частина міст, транспортна мережа яких проходить поблизу житлової забудови.

Наведені фактори, що обираються науковцями під час проведення експериментів із визначення рівнів транспортного шуму, не мають чіткого роз'яснення та вимог у нормативно-правовій законодавчій базі України. Затвердженим ще за радянських часів ГОСТ-ом 20444-85, наведені рекомендації відносно кліматичних умов, під час яких має проводитись експеримент, відстань від проїжджої частини до вимірювального мікрофону (що сягає 7,5 метрів) та мінімальна кількість транспортних засобів, що має проїхати в обох напрямках руху під час проведення натурних вимірювань, що становить 200 одиниць транспорту.

Закордонний досвід успішно демонструє, що впровадження моніторингу рівнів транспортного 
шуму $\epsilon$ вкрай необхідною для упорядкування вивчення цієї проблеми. Так, наприклад, в столиці Франції на вулицях міст з'явились шумовимірюючі пристрої, що обладнані чотирма мікрофонами та відеокамерою для фіксування перевищення допустимих рівнів шуму, та виявлення автомобілів, що завдають шкоди акустичному середовищу. Такий метод впроваджений для стимулювання власників автомобілів переходити на більш екологічний вид транспорту - електрокари.

Авторами роботи [8] пропонується новий підхід до системи моніторингу, основною ідеєю якого є ідентифікація основного джерела шуму за допомогою алгоритму класифікації акустичної схеми, що працює в бездротовому датчику та може використовуватись для автоматичного призначення вимірюваних рівнів звуку для різних джерел шуму.

Загалом, проведення моніторингу шуму обумовлюється необхідністю створення карт шуму населених міст відповідно до вимог Директиви 2002/49 Свропейського Союзу. Система мониторингу та картографування шуму - буденна практика для Європейських держав. Наразі у країнах-членах ЄС повстає питання у зниженні витрат, що направлені на проведення моніторингу шуму шляхом удосконалення та впровадження нових підходів у проведенні спостережень.

У зв'язку із тим, що картографування шуму потребує великих матеріальних зусиль та займає безліч часу, влада Італії прийняла рішення відповідно до якого можливе зниження витрат коштів та часу шляхом автоматизації процесу та створенню динамічних карт шуму.

В 2013 році був розроблений проект в рамках програми Life+2013, що фінансувалась Європейською Комісією. Метою проекту була розробка платформи для збору інформації із станцій моніторингу шуму. Така розробка була впроваджена у Римі вздовж кільцевої дороги. Для вимірювання рівнів звукового тиску в стратегічних місцях використовувалися мобільні контрольні пристрої, обладнані системами GIS. Було інвестовано в програмне забезпечення для розрахунку шуму в Лімі, програмне забезпечення для моніторингу шуму і кілька терміналів для моніторингу шуму. Докладніше цю практику описано у наукових закордонних публікаціях $[9,10]$.

\section{Виклад основного матеріалу}

Викладене вище дозволяє пропонувати впровадження рекомендації щодо проведення моніторингу шуму вулично-дорожньої мережі населених міст. Такі затверджені положення уможливлять проведення однотипних експериментів iз визначення рівнів транспортного шуму для набуття якісної оцінки впливів шумового потоку в придорожньому просторі для створення екологічно безпечного акустичного простору селітебних територій.

У положенні про державну систему моніторингу затверджене таке поняття моніторингу: аналітично-інформаційна система спостережень, збирання, оброблення, передавання, збереження та аналізу інформації про стан довкілля, прогнозування його змін i розроблення науково-обгрунтованих рекомендацій для прийняття рішень щодо запобігання негативним змінам стану довкілля та дотримання вимог екологічної безпеки.

Як зазначено Законом України «Про охорону атмосферного повітря», усі види та ступені впливу фізичних факторів на стан атмосферного повітря підлягають державному обліку. До фізичних факторів відносять шум повітряний, це шум, який випромінюється джерелом безпосередньо у повітря і поширюється повітряним шляхом.

Державною цільовою екологічною програмою проведення моніторингу навколишнього природного середовища «передбачено проведення комплексного моніторингу стану атмосферного повітря... фізичних факторів впливу на навколишнє природне середовище». Спостереження за фізичними чинниками впливу, зокрема, шумом, надасть змогу виявити причинно-наслідкові зв'язки між об'єктами навколишнього середовища та різновиди факторів впливу на них. Цей підхід забезпечить підвищення ефективності системи оцінки стану навколишнього природного середовища у цілому.

Проведення моніторингу рівнів шуму вуличнодорожньої мережі населених міст можна представити як циклічну процедуру спостережень, яка забезпечить створення та накопичення банку даних спостережень вуличного шуму. На рисунку 1 наведено запропоновану схему щорічного моніторингу.

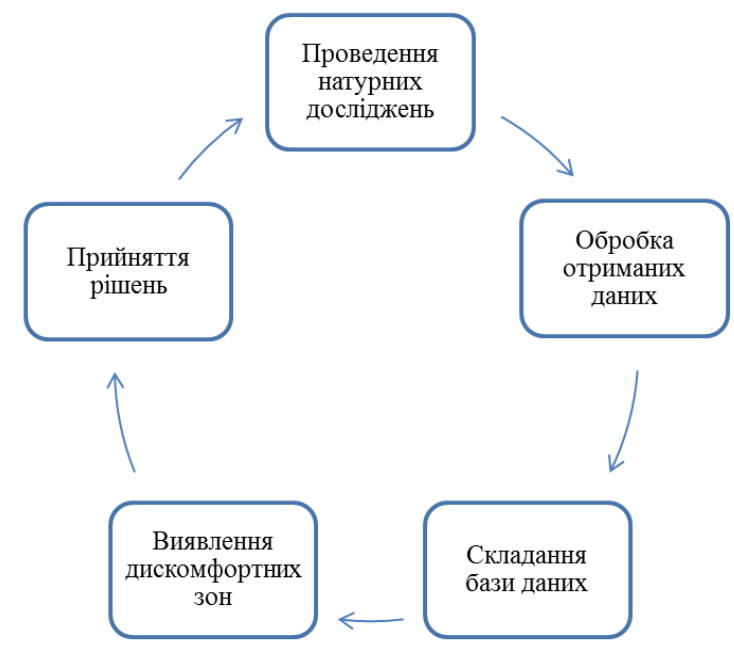

Рис. 1. Схема щорічного циклу моніторингу рівнів автотранспортного шуму 
Для впровадження системи моніторингу шуму, в першу чергу, необхідно обрати контрольні точки для проведення натурних вимірювань. При дотриманні вимог Директиви 2002/49/ СС, ці точки в межах міських територій житлової забудови мають обиратися з урахуванням:

- можливостей фіксації характеристик шуму у найбільш шумових позиціях на границях територій та біля фасадів житлових будівель;

- репрезентативності даних вимірювань щодо відображення акустичної ситуації на міських територіях житлової забудови загалом [8].

Проведення натурних досліджень

На першому етапі, для створення банку даних та обрання контрольних точок, необхідно провести виміри шуму на кожній вулиці дорожньої мережі населеного пункту, що мають усталену швидкість транспортного руху та на відстані не меншій ніж 50 м. від перехресть та зупиночних станцій громадського транспорту, протягом часового інтервалу, що охоплює проїзд 200 одиниць транспортних засобів в обох напрямках руху. Надалі, пропонується класифікувати транспортні магістралі на основі отриманих даних рівнів шуму та відповідно до ДБН В.2.3.-4:2015 «Автомобільні дороги», в якому приводяться категорії доріг населених міст із зазначеною інтенсивністю руху автомобільного транспорту. Для кожної наявної категорії доріг обирається одна вулиця із усталеним транспортним рухом та визначаються контрольні точки на яких мають розташовуватися вимірювальні прилади для визначення звукових характеристик транспортного потоку. Рекомендовані вимоги до обраної ділянки: контрольна вулиця має бути із асфальтобетонного покриття, ширина однієї проїзної полоси не менше ніж 3 метри. Відстань від краю проїзної частини до лінії житлової забудови не менше 10 метрів. Особливу увагу під час проведення натурних досліджень, необхідно приділяти тому факту, що повинні бути відсутніми огороджувальні конструкції, шумозахисні екрани, зелені насадження та інші фактори, що можуть екранувати звук. Рекомендована відстань для розташування вимірювального приладу - 7,5 метрів. Спостереження за рівнями шуму слід проводити щонайменш у трьох точках на обраній контрольній вулиці для регулювання шумового навантаження на урболандшафти за допомогою вимірюючих пристроїв-шумомірів. Шумоміри, що використовуються при моніторингу шуму мають мати частотну характеристику «А» із частотним діапазоном вимірювань 1 та 2 класів.

\section{Обробка отриманих даних}

Відповідно до рекомендацій Директиви 2002/49/ СС, вимірюваними параметрами шуму є еквівалентні $\mathrm{L}_{\mathrm{A} \text { еq }}$ рівні шуму та максимальні $\mathrm{L}_{\mathrm{A} \max }$ рівні шуму. Вимірювання зазначених величин слід проводити не менше трьох разів на день: у денний час з 7.00 до 19.00, вечірній з 19.00 до23.00 і нічний час доби з 23.00 до 07.00 годин. Необхідність використання максимальних рівнів шуму диктується вимогою санітарних норм оцінювати непостійний шум по еквівалентним i максимальним рівням звуку.

Еквівалентні та максимальні рівні шуму слід визначати згідно рекомендацій, що наведені у ГОСТ 23337. Максимальні рівні шуму $\mathrm{L}_{\mathrm{A} \text { max }}$ слід приймати за такі, що мають найбільше значення рівнів звуку за весь часовий інтервал виміру шуму.

Еквівалентні рівні шуму $\mathrm{L}_{\mathrm{A}}$ еq розраховуються за формулою, що наведена у ГОСТ 23337:

$$
L_{A e q}=10 \lg *\left(\frac{1}{N} * 10^{0.1 * L_{A t}}\right)
$$

де: $\mathrm{L}_{\mathrm{At}}$ - виміряні рівні звуку (дБА),

$\mathrm{N}$ - загальна кількість відліків рівнів звуку.

\section{Складання бази даних}

Моніторингові дослідження вимагають організації накопичення отриманих даних, що в подальшому повинні зберігатись та опрацьовуватись. Для роботи із результатами моніторингу шуму вулично-дорожньої мережі міст було розроблено інформаційний інструмент на основі Microsoft Access, що $\epsilon$ стандартною програмою пакету Microsoft Office та найбільш розповсюджена для виконання подібних задач.

Основними таблицями у базі даних моніторингу шуму є такі: Streets (назви та шифри вулиць, на яких проводиться моніторинг шуму); Point_Location (розташування точок моніторингу 3 врахуванням адрес та типу територіi); Monitoring_Data (дані розрахунків еквівалентних $\mathrm{L}_{\mathrm{A}}$ еq та максимальних рівнів $\mathrm{L}_{\mathrm{A}} \max$ шуму iз зазначенням дати та часу проведення вимірювань); Normative_Value (гранично допустимі рівні шуму в залежності від часу доби та типу територіі).

\section{Виявлення дискомфортних зон.}

Для виявлення зон акустичного дискомфорту необхідно провести порівняння отриманих значень рівнів шуму на контрольних точках із допустимими рівнями шуму відповідно до Наказу МО3 від 22.02.2019 № 463 «Про затвердження Державних санітарних норм допустимих рівнів шуму в приміщеннях житлових та громадських будинків і на території житлової забудови».

Для виявлення динаміки стану акустичного простору в населеному місті слід проводити порівняння отриманих результатів із даними за попередні роки. Для кожної контрольної точки проводиться визначення відхилень отриманих значень за наступною формулою: 


$$
\mathrm{A}_{\mathrm{i}}=\mathrm{L}_{1 . \mathrm{n} 1}-\mathrm{L}_{1 . \mathrm{n} 2},
$$

де: А - відхилення в і-тій контрольній точці (дБА); $\mathrm{L}_{1 \mathrm{n} 1}$ - еквівалентні рівні шуму в і-тій точці у поточному році (дБА);

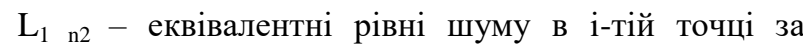
минулий рік (дБА).

Прийняття рішень.

На основі даних моніторингу та зіставлення отриманих результатів із гранично допустимим рівнями шуму необхідно розробити та впровадити дієві шумозахисні рішення. Це може бути створення шумозахисних споруд або адміністративні дії щодо регулювання транспортними потоками для зниження шумового навантаження на найбільш напружених магістралях та вулицях міст.

\section{Висновки}

Необхідність проведення моніторингу рівнів шуму вулично-дорожньої мережі населених міст закріплена на законодавчому рівні. Аналіз чинного нормативно-методичного забезпечення стосовно моніторингу шуму та аналітичний огляд вітчизняних наукових публікацій показали, що методичні рекомендації або порядок проведення моніторингу рівнів транспортного шуму вуличнодорожньої мережі не розроблені.

Спираючись на досвід Свропейських країн, доведено, що впровадження моніторингу шуму $\epsilon$ основоположнім фактором у забезпеченні екологічної безпеки акустичного простору.

У подальшому, створення регіональних програм моніторингу шуму забезпечить можливість регулювання техногенного навантаження (зокрема впливу шуму) на навколишне природне середовище та впровадження доступних та дієвих рекомендацій щодо подолання негативних наслідків від впливу підвищених рівнів шуму на здоров'я населення та урболандшафти в цілому.

Моніторинг комплексного впливу автотранспортного шуму повинен виконуватись 3 метою попередження чи зниження негативного впливу шуму на здоров'я населення та оточуюче середовище. Для цього на основі отриманих результатів, що занесені у єдину базу даних шуму, проводять складання шумових карт на території населеного пункту, на основі яких можливо виділити зони акустичного дискомфорту та подальша розробка організаційних, технічних та будівельних рішень щодо захисту від шуму.

Набуває подальшого розвитку проблематика із створення карт шуму для забезпечення обізнаності населення відносно якості акустичного простору.

Виходячи із викладеного вище, доцільно рекомендувати впровадження порядку проведення моніторингу шуму вулично-дорожньої мережі для визначення дискомфортних зон на території житлової забудови, розробки рекомендацій та прийняття рішень щодо поліпшення стану акустичного середовища та забезпечення екологічної безпеки в цілому.

\section{Література}

1. Куріс, Ю. В. Дослідження впливу автотранспорту на шумову безпеку міста в сталому розвитку урбанізованих територій [Текст] / Ю. В. Куріс, О.Б. Матяшева, К. В. Бєлоконь, Г. Б. Кожемякін // Збірник наукових прачь Дніпровського державного технічного університету (технічні науки). - 2017. - № 1(30). - С. 183-188.

2. Гилёв, В. В. Определение уровня шумового загрязнения примагистральной территории с усадебной застройкой [Електронний ресурс] / В. В. Гилёв, В. Н. Макарова, Т. А. Соболь, А. А. Лозиикая, О. А. Благинина // International scientific journal № 2, 2016 - Режим достуny: https://www.inter-nauka.com/issues/2016/2/793

3. Коваленко, Л. О. Визначення рівнів шуму на магістралях та вулииях міста [Текст] / Л. О. Коваленко // Міжвузівський збірник "Наукові нотатки". - 2014. - Вип. 46. C. 252-256.

4. Внукова, Н. В. Очінка ризику акустичного та вібраиіииного забруднення придорожнього простору ділянки автомобільної дороги [Електронний ресурс] / Н. В. Внукова, Г. М. Желновач, Н.В. Пархін // Вісник Харківського національного автомобільно-дорожнього університету. 2010. - № 48. Режим доступу: https://cyberleninka.ru/article/n/otsenka-riskaakusticheskogo-i-vibratsionnogo-zagryazneniyapridorozhnogo-prostranstva-uchastka-avtomobilnoydorogi/viewer

5. Саньков, П. М. Визначення шумових характеристик $i$ побудова карти шуму промислового підприємства [Текст] / П. М. Саньков, Н. О Ткач, В. М. Полторачька // Вісник Придніпровської державної академії будівництва та архітектури. - 2017.- № 4.- С. 231-232.

6. Шелудченко, Л. С. Екологічна оцінка шумового забруднення міста, спричиненого діяльністю автотранспортних засобів і стаціонарних джерел [Текст] / Л. С. Шелудченко, Д.В. Поліщук // Науково-практичний журнал «Екологічні науки». - 2018. - №4. - С. 10-13.

7. Решетченко, А. І. Дослідження впливу автотранспортних потоків на акустичне середовище урболандшафтів [Текст] /А. I. Решетченко // Комунальне господарство міст. Сер. Технічні науки та архітектура: зб.наук.пр. 2018. - №146. - C. 180-183.

8. Maijala, P., Shuyang, Z., Heittola, T., Virtanen, T. (n.d.) Environmental noise monitoring using source classification in sensors. Retrieved from https: //www.sciencedirect.com/science / article / pii / S0003682X17307533

9. Benocci, R., Bellucci, P., Peruzzi, L., Bisceglie, A., Angelini, F., Confalonieri, C., Zambon, G. (2019) Dynamic Noise Mapping in the Suburban Area of Rome (Italy). Environments, 6(7), 79, 1-17. Retrieved from https://doi.org/10.3390/environments6070079

10. Zambon, G., Benocci, R., Brambilla, G. (2016) Cluster categorization of urban roads to optimize their noise monitoring. Environ Monit Assess, 188: 26, 1-11. Retrieved from: https://link.springer.com/article/10.1007 / s10661-0154994-4 
11. Решетченко, А.І. Аналіз існуючих нормативів краӥн СС у порівнянні із вимогами украӥнського законодавства в сфері шумового навантаження в урбоекосистемі [Текст] / А.І. Решетченко, А. І. Борсук, Ю. І. Вергелес // Екологічна безпека та збалансоване ресурсокористування .- 2019. - № 2(2019). - C. 16-23.

\section{References}

1. Kuris, Yu. V., Matyasheve, A.B., Belokon, K.V., Kozhemyakin, G.T. (2017) Investigation of the effect of transport noise on the safety of the city in the sustainable development of urban territories. Collection of scientific works of the Dnieper state technical University (technical Sciences), 1(30), 183-188.

2. Gilev, V. V., Makarova, V.N., Sobol, T.A., Lesicka, A.A., Blaginin, A.A. (2016) Determination of the level of noise pollution near trunk road site with farmstead buildings. International scientific journal, 2. Retrieved from https://www.inter-nauka.com/issues/2016/2/793

3. Kovalenko, L. A. (2014) Determination of noise levels on highways and streets of the city. The interuniversity collection "Research notes", 46, 252-256.

4. Vnukova, N. V., Jelovac, G.M., Porn, N.I. (2010) Risk Assessment acoustic and vibration pollution of the roadside space, road section. Bulletin of Kharkov national automobile and highway University, 48. Retrieved from https://cyberleninka.ru/article/n/otsenka-riska-akusticheskogoi-vibratsionnogo-zagryazneniya-pridorozhnogo-prostranstvauchastka-avtomobilnoy-dorogi/viewer

5. Sankov, P. M., Weaver, N.A., Poltoratskaya, V.M. (2017) Determination of noise characteristics and mapping of noise of industrial enterprises. Bulletin of Prydniprovsk state Academy of construction and architecture, 4, 231-232.

6. Sheludchenko, L. S., Polischuk, D.V. (2018) Environmental assessment of noise pollution of the city caused by operation of vehicles and stationary sources. The Scientific-practical journal "Environmental science", 4, 10-13.

7. Reshetchenko, A. I. (2018) Investigation of the effect of automobile streams on the acoustic environment urbolandscape. Municipal economy of cities. Sir. Engineering and architecture: collection of Sciences.PR, 146, 180-183.

8. Maijala, P., Shuyang, Z., Heittola, T., Virtanen, T. (n.d.) Environmental noise monitoring using source classification in sensors. Retrieved from https: //www.sciencedirect.com/science / article / pii / S0003682X17307533

9. Benocci, R., Bellucci, P., Peruzzi, L., Bisceglie, A., Angelini, F., Confalonieri, C., Zambon, G. (2019) Dynamic Noise Mapping in the Suburban Area of Rome (Italy). Environments, 6(7), 79, 1-17. Retrieved from https://doi.org/10.3390/environments6070079

10. Zambon, G., Benocci, R., Brambilla, G. (2016) Cluster categorization of urban roads to optimize their noise monitoring. Environ Monit Assess, 188: 26, 1-11. Retrieved from: https://link.springer.com/article/10.1007 / s10661-0154994-4

11. Reshetchenko, A.I., Borsuk, A.I., Vergeles, Yu.I. (2019) Analysis of the existing EU standards in comparison with the requirements of the Ukrainian legislation in the field of noise load in the urban ecosystem. Ecological security and balanced resource use, 2 (2019), 16-23.

Рецензент: д-р техн. наук проф. Ф.В. Стольберг, Харківський національний університет міського господарства імені О.М. Бекетова, Харків, Україна

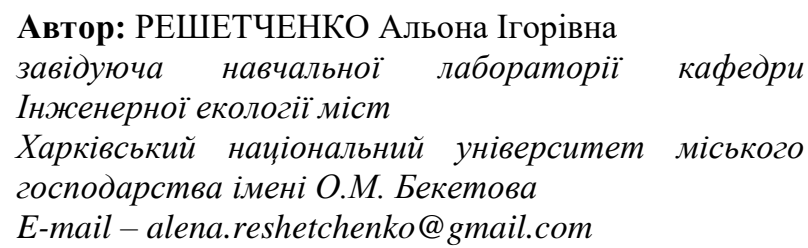

\section{RECOMMENDATIONS FOR THE IMPLEMENTATION OF NOISE MONITORING OF THE ROAD AND ROAD NETWORK OF THE POPULATION}

A. Reshetchenko

O.M. Beketov National University of Urban Economy in Kharkiv, Ukraine

The main source of noise pollution of cities is motor transport. This work substantiates the necessity of monitoring the noise of the road network and recommendations on organization of monitoring of noise. The author analyzed the legal framework of Ukraine on the organization of the monitoring revealed the absence of an approved at the legislative level plan or methodical recommendations on organization of monitoring of noise. Analysis of scientific publications, which described measurements of transport and noise identified the lack of organized and odnopoliy measurements and interpretation of results.

The author of the article analyzes the international experience in monitoring noise of the road network of cities. Have enough successful experience in the organization and conduct of monitoring in countries such as France and Rome. This method is introduced to stimulate motorists to switch to more ecological form of transport-electric cars.

Monitoring complex effects of motor noise must be implemented to prevent or reduce the effects of noise on human health and the environment. On the basis of the results listed in the unified database of the noise, hold the drawing up of noise maps for the territory of the settlement, on the basis of which it is possible to identify areas of acoustical discomfort and further development of organizational, technical and construction solutions for protection from noise.

On the basis of the results obtained in the single database about the noise, they produce maps of noise on the territory of the settlement, which can be used to identify areas of acoustical discomfort and further development of organizational, technical and construction solutions for noise protection.

The problem of creating noise maps to raise awareness of the population regarding the quality of the acoustic space develops further.

Keywords: noise, monitoring, motor transport, surveillance, highway 